\title{
Фізична реабілітація хлопців старшого дошкільного віку з плоскостопістю із використанням засобів та елементів гри у футбол
}

\author{
УДК 796:617.586-053.4-085+061.237-055.15
}

\section{І. О. Жарова, П. П. Чередніченко}

Національний університет фізичного виховання і спорту України, Київ, Україна

\begin{abstract}
Резюме. Велика кількість відхилень у стані опорно-рухового апарату дітей старшого дошкільного віку свідчить про те, що чинні організаційно-методичні підходи до використання засобів фізичної реабілітації та фізичного виховання повною мірою не забезпечують профілактики розвитку деформацій склепінь стопи та їх корекції. Систематичне тренування м'язів нижніх кінцівок - один з основних засобів профілактики плоскостопості. Однак застосування лікувальної фізичної культури часто не дає бажаного результату. Зазвичай використовувані спеціальні фізичні вправи не завжди в достатньому ступені впливають на найважливіші м'язові групи. Поряд із використанням регулярних фізичних вправ з метою профілактики й корекції плоскостопості необхідно здійснювати пошук нових ефективних засобів тренування сили м'язів стопи й гомілки. Одним з ефективних засобів фізичного виховання, що має на меті посилення й зміцнення м'язів нижніх кінцівок і відповідає віковим особливостям старших дошкільників, є вправи, які включають елементи спортивних ігор, зокрема футболу. Крім коригуючої функції, використання елементів футболу впливає на розвиток фізичних якостей, рухових навичок, інтелектуальних здібностей, сприяє підвищенню рівня захисних функцій організму й формуванню інтересу до фізичної культури та спорту. Вищевикладене визначило мету - розробити технологію фізичної реабілітації із застосуванням засобів футболу для хлопців 4-6-річного віку із плоскостопістю. Ця технологія ґрунтується на дидактичних принципах і принципах фізичної реабілітації, на організаційних та методичних основах процесу відновлення дітей із плоскостопістю та здійснюється відповідно до трьох етапів реабілітації із використанням усіх можливих засобів, форм, методів і принципів фізичного виховання та фізичної реабілітації в єдності, реалізуючи тим самим корекційну, оздоровчу, виховну та освітню функції фізичного виховання та фізичної реабілітації, забезпечуючи їх зв'язок із підготовкою до школи та формуванням гармонійно розвиненої особистості.
\end{abstract}

Ключові слова: фізична реабілітація, хлопці старшого дошкільного віку, плоскостопість, засоби футболу.

Резюме. Большое количество отклонений в состоянии ОДА детей старшего дошкольного возраста свидетельствует о том, что существующие организационно-методические подходы к использованию средств физической реабилитации и физического воспитания не в полной мере обеспечивают профилактику развития деформаций сводов стопы и их коррекцию. Систематическая тренировка мышц нижних конечностей - одно из основных средств профилактики плоскостопия. Однако лечебная физическая культура часто не приносит желаемый результат. Обычно используемые специальные физические упражнения не всегда в достаточной степени влияют на наиболее важные мышечные группы. Наряду с использованием регулярных физических упражнений с целью профилактики и коррекции плоскостопия необходимо осуществлять поиск новых эффективных средств тренировки силы мышц стопы и голени. Одним из эффективных средств физического воспитания, которое направлено на повышение силы и укрепление мышц нижних конечностей и соответствует возрастным особенностям старших дошкольников, являются физические упражнения с элементами спортивных игр, в частности футбола. Кроме корригирующей функции, использование элементов футбола влияет на развитие физических качеств, двигательных навыков, интеллектуальных способностей, способствует повышению уровня защитных функций организма и формированию интереса к физической культуре и спорту. Вышеизложенное определило цель работы - разработать технологию физической реабилитации с применением средств футбола для мальчиков 4-6-летнего возраста с плоскостопием. Разработанная технология основывается на дидактических принципах 
и принципах физической реабилитации, на организационных и методических основах процесса восстановления детей с плоскостопием и осуществляется согласно трех этапов реабилитации с применением всех возможных средств, форм, методов и принципов физического воспитания и физической реабилитации в единстве, реализуя тем самым коррекционную, оздоровительную, воспитательную и образовательную функции физического воспитания и физической реабилитации, обеспечивая их связь с подготовкой к школе и формированием гармонично развитой личности.

Ключевые слова: физическая реабилитация, ребята старшего дошкольного возраста, плоскостопие, средства футбола.

Abstract. A large number of variations in the state of ODA of senior pre-school children suggests that the existing organizational and methodological approaches to usage of physical rehabilitation and physical training do not fully ensure the prevention of the development of foot arches deformation and their correction. Systematic training of the lower extremity muscles is one of the main means of prevention of flat-foot. However, therapeutic physical training not always brings the desired result. Commonly used special exercises not always sufficiently affect the most important muscle groups. Along with usage of regular exercises for the prevention and correction of flat feet, one need to search for new and effective means of strength training of muscles of the foot and the lower leg. One of the most effective means of physical education, which is aimed at strengthening of the muscles of the lower extremities, and meets the age characteristics of the senior preschool children are exercises with elements of sports games, and football, in particular. Besides correcting function, the use of elements of football influences the development of physical qualities, motor skills, intellectual abilities, increases the level of protective functions of the body and the formation of interest to physical culture and sport. The above presented has determined the purpose of the work - to develop the technology of physical rehabilitation with application of football means for boys aged 4-6 years with flat feet. The developed technology is based on the didactic principles and those of physical rehabilitation, on organizational and methodological foundations of the recovery process of children with flat foot. It has three stages of rehabilitation with usage of all possible means, forms, methods and principles of physical education and physical rehabilitation in unity, realizing thereby correctional, recreational, educative function of physical education and physical rehabilitation, ensuring their connection with the preparation for the school and the formation of a harmoniously developed personality.

Keywords: physical rehabilitation, children of senior preschool age, flat-footedness, football means.

Постановка проблеми. На сьогодні попри різноманітність програм, впроваджуваних у дошкільних навчальних закладах (ДНЗ), проблема вдосконалення фрізичного виховання дітей 3 одночасною корекцією порушень опорно-рухового апарату (ОРА) залишається актуальною. Це підтверджується тенденцією погіршення стану здоров'я, зниженням рівня рухової активності дітей дошкільного віку [1].

Аналіз літературних джерел дозволив виявити незначну кількість програм фрізичного виховання дітей, спрямованих на корекцію порушень OPA, зокрема, функціональних і статичних деформацій стопи. Програми з фрізичного виховання дошкільників із плоскостопістю побудовані здебільшого на застосуванні спеціальних і загальнорозвиваючих фрізичних вправ, при використанні яких потреба дітей у руховій активності задовольняється під час їх перебування в ДНЗ лише на 45-50 \%, навіть при триразовому проведенні фрізкультурних занять [4].

Отже, у системі заходів із запобігання плоскостопості у дітей головна роль належить засобам фрізичного виховання i, зокрема, фрізичним вправам, механізми профрілактичного і корекційного впливу яких у даний час вивчені досить добре [6, $8,11]$. Хоча деякими програмами дошкільного фрізичного виховання передбачено формування склепіння стопи у дітей, однак досі не визначено засоби і методи вирішення цього завдання, а сорормовані підходи, як очевидно, $є$ недостатньо ефрективними. Таким чином, існують такі суперечності: між соціальною потребою в запобіганні плоскостопості у дітей і фрактичними можливостями ДНЗ в її реалізації; між необхідністю підвищення профілактичної ефрективності засобів фрізичного виховання, які використовуються в ДНЗ, і відсутністю науково обгрунтованої системи їх застосування щодо запобігання плоскостопості у дошкільників; між необхідністю вдосконалення профрілактичної фрізкультурно-оздоровчої роботи в ДНЗ і недостатнім рівнем її науково-методичного забезпечення в педагогічній науці і практиці, що не дозволяє в повній мірі використовувати можливості фрізичного виховання в запобіганні плоскостопості у дітей [12]. У зв'язку з вищесказаним, важливими $є$ пошук і розроблення програм рухової активності дошкільників у позаурочний час, спрямованих на розвиток фрізичних якостей, функціональних і резервних можливостей організму дітей, а також профрілактику й корекцію деформацій ОРА [10].

Аналіз досліджень і публікацій. Аналіз спеціальної науково-методичної літератури показав, що система фрізичного виховання дітей у дошкільних освітніх установах фрункціонує недостатньо 
есрективно, що обумовлює необхідність ії вдосконалення як у плані традиційно використовуваних, так і впровадження нових засобів, форм і методів занять фрізичними вправами [2].

У даному контексті особливий інтерес становить використання ігрового методу і вправ 3 арсеналу спортивних ігор у системі фрізичного виховання дітей старших груп у ДНЗ і в позаурочний час в умовах спортивно-ігрового центру. Саме у дошкільному (від 4 до 6 років) віці гра стає провідною діяльністю дитини. Фахівці підкреслюють, що гра $€$ оптимальною основою для фрізичного, розумового, соціального й емоційного розвитку $[5,7]$.

Спортивним іграм найчастіше відводиться місце в заняттях, що виходять за рамки обов'язкових і використовуються дітьми як засоби організації самостійних форм рухової активності. Однак, на думку більшості фахівців [3], спортивні ігри та їх елементи сприяють поліпшенню функціонального стану органів і систем, фрізичному розвитку й фрізичній підготовці дошкільників. Підбираючи ігри для дітей з плоскостопістю, слід керуватися тим, що покладені в їх основу рухові вправи, поряд із загальним оздоровленням організму дитини, мають забезпечувати вирішення таких завдань: зміцнення м'язів і зв'язок стопи і гомілки, розвиток силової витривалості м'язів нижніх кінцівок; фоомування навички раціональної установки стоп, правильної ходи; формування склепінь стопи [8-10]. Ці завдання можуть бути вирішені завдяки застосуванню елементів ігор, де дії з м'ячем виконуються ногами, тобто фрутболу.

Таким чином, елементи футболу можуть виступати як засіб зміцнення м'язового апарату, що відповідає за утримання склепіння стопи, й елемент коригуючої гімнастики при вже розвинених статичних деформаціях стопи.

Мета дослідження - розробити технологію фрізичної реабілітації із застосуванням засобів фрутболу для хлопців 4-6-річного віку із плоскостопістю в умовах спортивно-ігрового центру.

Методи та організація дослідження. Під час досліджень використано такі методи, як аналіз спеціальної та науково-методичної літератури, педагогічне спостереження. Дослідження були проведені на базі фрутбольного клубу «Footballkids», м. Київ. В обстеженні брали участь 72 хлопця старшого дошкільного віку.

Зв'язок роботи 3 науковими програмами, планами, темами. Роботу виконано згідно зі Зведеним планом НДР у сфрері фрізичної культури і спорту на 2011-2015 рр. Міністерства освіти й науки, молоді та спорту України за темою 4.4. «Удосконалення організаційних і методичних основ програмування процесу фрізичної реабілітації при дисфункціональних порушеннях у різних системах організму людини» (номер держреєстрації 0111U001737).

Результати дослідження та їх обговорення. Вивчення науково-методичної літератури свідчить, що в даний час система реабілітації дітей $з$ порушенням функцій нижніх кінцівок передбачає використання різних засобів і методів кінезитерапії, де особливе місце належить гімнастичним і спортивно-прикладним вправам, спрямованим на зміцнення м'язів, що фрормують склепіння стопи $[2,6]$.

Аналіз змісту програм фрізичної реабілітації дітей дошкільного віку із плоскостопістю виявив відсутність даних про використання елементів гри у фрутбол як з метою профрілактики статичних порушень, так і для корекції вже розвиненої плоскостопості.

Однак, на нашу думку, основні технічні прийоми гри (пересування, ведення м'яча, удари по м'ячу, його зупинення) мають сприяти зміцненню м'язово-зв'язкового апарату нижніх кінцівок.

При виконанні різних способів удару по м'ячу (носком, підйомом стопи, внутрішньою або зовнішньою стороною стопи), способів ведення (носком, внутрішньою або зовнішньою стороною стопи, підйомом, підошвою) і варіантів ведення м'яча (тільки однієї ногою, почергове використання правої i лівої ноги) беруть участь як м'язи стегна й гомілки, так і м'язи надп'ятковогомілкового суглоба, що відповідають за утримання склепіння стопи [3].

На підставі даних літературних джерел, функціонального стану ОРА, що впливають на характер і спрямованість реабілітаційних заходів, ми розробили технологію ффізичної реабілітації хлопців 4-6-річного віку із плоскостопістю (рис. 1). Вона

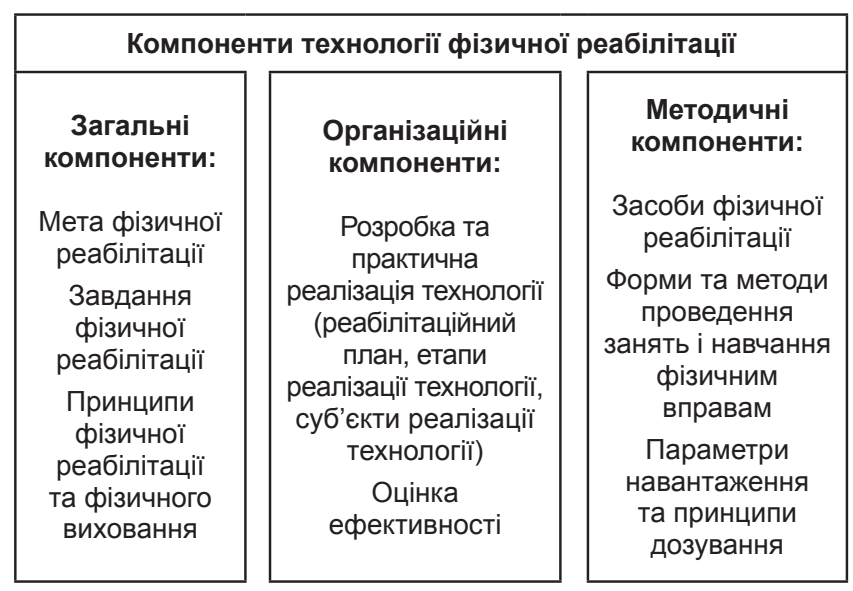

Рисунок 1 - Блок-схема технології фрізичної реабілітації хлопців 4-6-річного віку із плоскостопістю 


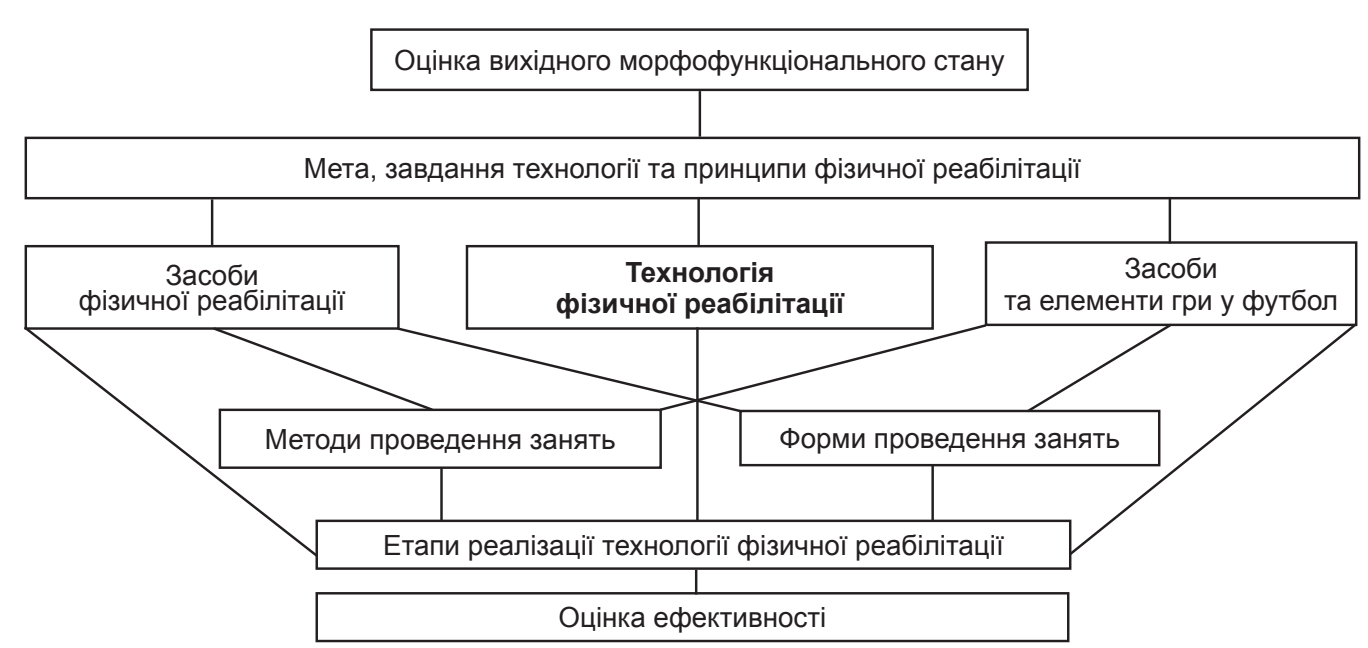

Рисунок 2 - План реабілітаційного процесу хлопців 4-6-річного віку із плоскостопістю

ґрунтується на дидактичних принципах і принципах орізичної реабілітації, на організаційних та методичних основах процесу відновлення дітей із плоскостопістю.

До загальних компонент технології фрізичної реабілітації належать мета, завдання та принципи фрізичної реабілітації. Метою реабілітації хлопців із плоскостопістю було виправлення деформацій та відновлення опорно-ресорних властивостей стопи.

ОсноВні заßдання реабілітації хлопців старшого дошкільного віку з плоскостопістю:

- зміцнення м'язово-зв'язкового апарату;

- покращення діяльності опорно-рухового апарату;

- поліпшення обмінних процесів шляхом посилення крово- і лімфообігу в кінцівці;

- відновлення втрачених фрункцій;

- вдосконалення фрізичних якостей та рухових умінь;

- профрілактика розвитку можливих ускладнень.

Принципи реалізаціі технології фозичної реабілітації [6]: принцип активної та свідомої участі дитини та членів її родини в процесі реабілітації; принцип своєчасного та раннього початку проведення реабілітаційних заходів; принцип систематичності та безперервності проведення реабілітаційних заходів; принцип доступності та поступовості; принцип етапності реабілітаційного процесу; принцип наочності, спрямований на зв'язок чуттєвого сприйняття з мисленням; принцип індивідуалізації; принцип комплексного застосування засобів фрізичної реабілітації та фрутболу; принцип задоволення рухової фрункції.

Водночас ми вважаємо за необхідне дотримуватися спеціальних, прийнятих у теорії й методиці фрізичного виховання принципів, які відображають закономірності фрізичного виховання [7]: принципу неперервності, який виражає основні закони побудови занять у фрізичному вихованні; принципу поступового нарощування розвивально-тренувальних впливів, що забезпечує тенденцію поступового збільшення навантаження; принципу адаптивного збалансування динаміки навантажень, який спрямований на нормування навантаження; принципу циклічності, котрий полягає в повторенні в певній послідовності занять, що забезпечує підвищення тренованості; принципу вікової адекватності, який забезпечує врахування вікових і індивідуальних особливостей дитини.

До організаційних компонент було віднесено розробку та практичну реалізацію технології фрізичної реабілітації з активним залученням суб'єктів реалізації технології (діти, батьки, методисти).

Відповідно до виявлених окремих соматичних і фрункціональних порушень хлопців 4-6-річного віку із плоскостопістю, для досягнення більш вираженого реабілітаційного ефекту технологію фрізичної реабілітації створювали за таким планом (рис. 2).

Перший етап - оцінювання вихідного морфофункціонального стану дитини, яке полягає в опитуванні (наявність скарг, тривалість захворювання, проведене лікування та його ефективність, проведені реабілітаційні заходи), огляді (під час якого фріксують загальний стан, фрізичний розвиток, пропорційність тілобудови, рухову поведінку дитини, стан локомоторного апарату), вимірюванні антропометричних показників (зріст, маса тіла), проведенні біомеханічних (фотометрія, міотонометрія) і педагогічних (тестування рівня фрізичної підготовленості та спостереження 
за виконанням хлопцями старшого дошкільного віку елементів гри у фрутбол) досліджень.

Другий етап - фрормування мети і завдань фрізичної реабілітації; підбір принципів відповідно до даних, визначених під час оцінювання морфофункціонального стану дитини.

Третій етап - розроблення та реалізація технології фрізичної реабілітації, у ході якої особливе місце належить визначенню спеціальних коригувальних і реабілітаційних заходів.

На підставі отриманих даних першого етапу, обраної мети, завдань, загальних положень i принципів фрізичного виховання та фрізичної реабілітації було розроблено технологію фрізичної реабілітації хлопців 4-6-річного віку із плоскостопістю: визначено етапи реалізації технології фрізичної реабілітації (підготовчий, основний і заключний), їхні цілі та завдання, тривалість, засоби реабілітаційного впливу, форми (процедура лікувальної гімнастики із використанням засобів та елементів гри у фрутбол, ранкова гігієнічна гімнастика, елементи спорту) і методи їх проведення, а також параметри навантаження (вихідне положення, темп, ритм, амплітуда, тривалість, кратність, інтенсивність, щільність навантаження тощо) і організаційно-методичні вказівки.

Четвертий етап - оцінювання ефективності технології фрізичної реабілітації.

Як вже зазначалося, до основних суб'єктів, які безпосередньо брали учать у реалізації технології фрізичної реабілітації належать хлопці старшого дошкільного віку із плоскостопістю, їх батьки, а також інструктори-методисти, що проводили заняття $з$ дітьми.

На підставі аналізу спеціальної літератури в сорері фрізичного виховання та фрізичної реабілітації $[8,10]$, логічного аналізу та практичного досвіду роботи ми встановили, що до методичних основ процесу фрізичної реабілітації при плоскостопості у дітей можна віднести: засоби фрізичної реабілітації; фрорми та методи проведення занять і навчання фрізичних вправ; принципи дозування та параметри навантаження.

Комплексне лікування, спрямоване на відновлення опорно-ресорної функції, збільшення склепіння стопи, ґрунтувалося на застосуванні певних засобів, а саме:

- кінезитерапії із застосуванням систематичних фрізичних вправ та елементів фрутболу як основних засобів фрізичної реабілітації, проведених у фоорі ранкової гігієнічної гімнастики, лікувальної гімнастики, ігрового заняття.

\section{- масажу;}

- природних фокторів - кліматотерапії, місцевих ванн;
ТАБЛИЦЯ 1 - Розподіл блоків футбольних вправ протягом курсу реабілітації

\begin{tabular}{|l|c|c|c|c|c|}
\hline \multirow{2}{*}{ Етап реабілітації } & \multicolumn{5}{|c|}{ Блоки вправ } \\
\cline { 2 - 7 } & $\mathbf{1}$ & $\mathbf{2}$ & $\mathbf{3}$ & $\mathbf{4}$ & $\mathbf{5}$ \\
\hline Підготовчий (3 міс.) & $\mathrm{X}$ & $\mathrm{X}$ & $\mathrm{X}$ & & \\
\hline Основний (6 міс.) & $\mathrm{X}$ & $\mathrm{X}$ & $\mathrm{X}$ & $\mathrm{X}$ & $\mathrm{X}$ \\
\hline Заключний (3 міс.) & $\mathrm{X}$ & $\mathrm{X}$ & $\mathrm{X}$ & $\mathrm{X}$ & $\mathrm{X}$ \\
\hline
\end{tabular}

Примітки: 1 - вправи для ознайомлення з новим матеріалом; 2 - вправи змішаного типу, спрямовані на закріплення матеріалу, що вивчається; 3 - варіативні вправи з використанням складніших варіантів уже засвоєних рухових дій; 4 тренувальні вправи, що включають змагальні вправи та ігри з м'ячем, спрямовані на розвиток функціональних і рухових якостей; 5 - інтегровані вправи, що включають використання елементів гри у футбол для вирішення пізнавальних завдань $i$ закріплення матеріалу.

\section{- ортопедичних заходів.}

В основу побудови процедури лікувальної гімнастики для хлопців із плоскостопістю було покладено принцип ступінчасто-наростаючого навантаження. Для відновлення опорно-ресорних властивостей стопи, зміцнення м'язовозв'язкового апарату нижніх кінцівок, склепіння стопи, підвищення функціонування серцево-судинної і дихальної систем тощо ми застосовували такі фрізичні вправи: гімнастичні (активні, динамічні та статичні загальнорозвивальні та спеціальні вправи для м'язів нижніх кінцівок, тулуба; коригувальні вправи, вправи із предметами та на знарядді, швидкісно-силові вправи, вправи на розтягування, на координацію та рівновагу, вправи на розслаблення); дихальні (статичні, динамічні); спортивно-прикладні (різні варіанти та види ходьби, біг, стрибки, метання тощо); ігри (рухливі ігри, засоби та елементи гри у фрутбол).

Для навчання елементам гри у фрутбол було обрано рухові дії, рекомендовані провідними фрахівцями для цієї вікової групи, які послідовно засвоювалися дітьми протягом навчального року і були розподілені на 5 груп: на розвиток відчуття м'яча; на навчання ударам; на навчання зупинення і передач; на навчання ведення; комбіновані вправи, спрямовані на закріплення і вдосконалення гри у фрутбол [3, 8].

Вправи всередині груп і самі групи були взаємопов'язані між собою і забезпечували спадкоємність і послідовність у вирішенні завдань навчання та реабілітації. Зміст кожної окремої групи вправ відповідав стадіям фрормування певного рухового вміння та етапу реабілітації (табл. 1).

Водночас, фрізичні вправи, які сприяють розвитку фрізичних якостей, ми класифрікували таким чином: вправи на розвиток координаційних 
ТАБЛИЦЯ 2 - Модель формування рухових умінь і навичок для гри «футбол» [9]

\begin{tabular}{|c|c|c|}
\hline $\begin{array}{l}\text { Технічні прийоми } \\
\text { для засвоєння гри }\end{array}$ & Фізичні вправи & $\begin{array}{l}\text { Фізичні якості, } \\
\text { що формуються }\end{array}$ \\
\hline $\begin{array}{l}\text { Ведення та передача м'яча внутрішньою } \\
\text { стороною стопи }\end{array}$ & \multirow{5}{*}{$\begin{array}{l}\text { Ходьба } \\
\text { Біг, біг на } 30 \text { м з прискоренням; біг уперед спиною, } \\
\text { човниковий біг, біг «змійкою» (між предметами); стрибки } \\
\text { у довжину, у висоту, з розбігу }\end{array}$} & \multirow{5}{*}{$\begin{array}{l}\text { Швидкість, } \\
\text { спритність, } \\
\text { гнучкість, сила, } \\
\text { витривалість }\end{array}$} \\
\hline Ведення, розвороти та передача м'яча убік & & \\
\hline $\begin{array}{l}\text { Удари м'яча носком, п'ятою ноги (удари у ворота, } \\
\text { передача м'яча в сторони, назад, уперед) }\end{array}$ & & \\
\hline $\begin{array}{l}\text { Зупинення м'яча серединою підйому стопи або } \\
\text { підошвою }\end{array}$ & & \\
\hline Удари м'яча «щокою» ноги, не зупиняючи м'яча & & \\
\hline Передача м'яча партнерові & \multirow{3}{*}{$\begin{array}{l}\text { Загальнорозвивальні рухи: відведення рук у сторони, } \\
\text { підняття вгору; нахили тулуба вперед, у сторони; повороти } \\
\text { тулуба в сторони; колові рухи руками; піднімання ніг (з різних } \\
\text { вихідних положень) з метою розвитку м'язів живота та ніг. } \\
\text { Рухливі ігри: «Збий кеглю», «Прокоти м'яч у ворота», «М'яч } \\
\text { під планкою», «Перекинь через планку», «Біг змійкою», } \\
\text { «Третій лишній», «Ми веселі діти», «Вудочка» та ін. }\end{array}$} & Гнучкість \\
\hline $\begin{array}{l}\text { Ведення м'яча (котіння) носком, внутрішньою } \\
\text { стороною стопи до воріт }\end{array}$ & & Сила, гнучкість \\
\hline Забивання м'яча головою & & Гнучкість \\
\hline Вкидання м'яча обома руками з-за голови & Метання м'яча з-за голови & Спритність, сила \\
\hline
\end{tabular}

здібностей, вправи на розвиток швидкості, вправи на розвиток сили, вправи на розвиток гнучкості, вправи на розвиток витривалості (табл. 2).

3 метою оптимізації навчання залежно від його змісту i конкретних дидактичних завдань вважаємо за необхідне використовувати різні методи наъчання: оволодіння знаннями, руховими вміннями й навичками, вдосконалення рухових навичок і розвитку фрізичних якостей; а також методи проведення занять: малогруповий, груповий і самостійний.

Найважливішими аспектами методики застосування фрізичних вправ із корегувальною метою в дітей дошкільного віку із плоскостопістю були параметри навантаження та принципи дозування

\section{Література}

1. АнисимоВа Т. Г. Формирование правильной осанки и коррекция плоскостопия у дошкольников : рекомендации, занятия, игры, упражнения / Т. Г. Анисимова, С. А. Ульянова ; под ред. Р. А. Ереминой. - [2-е изд.] - Волгоград : Учитель, 2011. - 146 с.

2. Бичук І. О. Вплив програми профрілактики плоскостопості на біомеханічні характеристики стопи дошкільнят / І. О. Бичук, А. І. Альошина // Педагогіка, психологія та медико-біологічні проблеми фізичного виховання і спорту. - Х. : ХОВНОКУ, 2011. - № 2. - С. 10-13.

3. Варюшин В. В. Тренировка юных фрутболистов: учеб. пособие для студентов вузов / В. В. Варюшин // Российский футбольный союз. - М. : Физ. культура, 2007. - 112 с.

4. Вільчковський E. C. Теорія і методика фрізичного виховання дітей дошкільного віку : навч. посіб. / Е. С. Вільчковський, О. І. Курок. - [2-ге вид., перероб. і доп.] Суми : Університет. кн., 2005. - 428 с.

5. Каменская В. Г. Концептуальные основы здоровьесберегающих технологий развития ребенка дошкольного и фрізичних вправ, до яких належать: 1) вибір вихідного положення; 2) вид вправи; 3) принцип розсіяності фрізичного навантаження; 4) кількість повторень вправ та їх тривалість; 5) темп рухів; 6) ритм рухів; 7) амплітуда рухів; 8) точність виконання рухів; 9) простота та складність рухів; 10) ступінь прикладеного зусилля у виконанні вправ; 11) емоційний фактор; 12) співвідношення загальнорозвиваючих, спеціальних і дихальних вправ; 13) щільність навантаження.

Перспективи подальших досліджень. Надалі буде перевірено ефективність розробленої технології корекції порушень опорно-ресорних властивостей стопи хлопчиків старшого дошкільного віку, які займаються футболом.

\section{References}

1. Anisimova T. G., Ulyanov S. A. (2011). Correct posture formation and flat-foot correction in preschool children: recommendations, games, exercises. 2 ed., Volgograd: Master (in Russian)

2. Bychuk I. O., Aleshina A. I. (2011) Influence prevention programs to flat foot biomechanical characteristics of preschoolers. Pedagogy, psychology, medical-biological problems of physical education and sports sciences, Kh: HOVNOKU, no 2, pp. 10-13. (in Ukrainian)

3. Varyushin V. V. (2007) Training young football players: a textbook for university students. Russian Football Union, M.: Physical Education (in Russian)

4. Vilchkovskyy E. S., Kyrok A. I. (2005) Theory and methods of physical education of preschool children, teach. Guidances. $2^{\text {nd }}$ ed. Amounts University. (in Ukrainian)

5. Kamenskaya V. G., Kotov S. A. (2008) Conceptual Framework of health-technology development of the child of pre-school and primary school age: textbook. SPb: RGPU. Herzen (in Russian) 
младшего школьного возраста : учеб. пособие / В. Г. Каменская, С. А. Котова; под ред. Н. А. Ноткиной. - СПб : РГПУ им. А. И. Герцена, 2008. - 224 с.

6. КозыреВа О. В. Лечебная физкультура для дошкольников (при нарушениях опорно-двигательного аппарата) : пособие для инструкторов лечебной физкультуры, воспитателей и родителей / О. В. Козырева. - М. : Просвещение, 2003. - 112 с.

7. Круцевич Т. Ю. Теорія і методика фризичного виховання : підруч. / Т. Ю. Круцевич. - К. : Олімп. л-ра, 2008. T. 2. -320 c.

8. Нарскин Г. И. Система просрилактики и коррекции отклонений опорно-двигательного аппарата у детей дошкольного и школьного возраста средствами физического воспитания : автореф. дисс. на соискание научной степени д-ра пед. наук : спец. 13.00.04 / Г. И. Нарскин. - 2003. 29 c.

9. Орджоникидзе 3. Г. Физиология футбола / 3. Г. Орджоникидзе, В. И. Павлов; Российский футбольный союз, Объединение отечественных тренеров по фрутболу. - М. : Человек: Олимпия, 2008. - 240 с.

10. Попов П. А. Оптимизация комплекса восстановительного лечения плоскостопия у лиц, занимающихся спортом : дисс. ... канд. мед. наук : спец. 14.01 .15 / П. А. Попов. - Самара, 2010. - 124 с.

11. Сергієнко К. М. Контроль та профрілактика порушень опорно-ресорної функції стопи школярів у процесі фрізичного виховання : автореф. дис. на здобуття наук. ступеня канд. із фріз. вих. і спорту / К. М. Сергієнко. - К., 2004. -20 с.

12. Теория и методика фризической культуры дошкольников: учеб. пособие для студентов академий, университетов, институтов фризической культуры и фракультетов фризической культуры педагогических вузов / под ред. С. О. Филипповой, Г. Н. Пономарева. - СПб : «ДЕТСТВОПРЕСС»; М.: ТЦ «СФЕРА», 2008. - 656 с.

aniri2002@ukr.net

\section{Спортивна медицина і фізична реабілітація, №2, 2016}

6. Kozyreva O. V. (2003) Therapeutic exercise for preschoolers (in disorders of the musculoskeletal system): A guide to physical therapy instructors, educators and parents. M.: Education (in Russian)

7. Krutsevych T. (2008) Theory and Methods physical education: textbook. K.: Olympic. I-ra, t. 2 (in Ukrainian)

8. Narskin G. I. (2003) System is the prevention and correction of abnormalities of the musculoskeletal system in children of preschool and school age means of physical training (PhD Thesis), Gennady Ivanovich Narskin. (in Russian)

9. Ordzhonikidze G., Pavlov V. I. (2008) Physiology of football. Russian Football Union, the Association of Russian football coach. M.: People: Olympia (in Russian)

10. Popov P. A. (2010) Optimization of complex restorative treatment of flatfoot by persons engaged in sports (PhD Thesis), Samara (in Russian)

11. Sergienko K. M. (2004) Control and prevention of musculoskeletal function foot-spring students in physical education: author. dissertation for obtaining science (PhD Thesis), Kiev (in Ukrainian)

12. Philipova S. O., Ponomareva G. N. (2008) Theory and methods of physical training of preschool children: proc. manual for students of academies, universities, institutes of physical education and faculties of physical training of pedagogical universities. St. Petersburg: «Childhood-Press», M.: TC «SCOPE» (in Russian) 